\title{
Editorial
}

\section{Tribute to Jacques Jeandot}

Professor Jacques Jeandot passed away unexpectedly on June 12, 2018.

He was an important figure in the Société Française de Chirurgie Orale (SFCO) [French Society of Oral Surgery] whose scientific publication is the Journal of Oral Medicine and Oral Surgery (JOMOS). He served as the president of the society between 1994 and 2000. As the new president of the SFCO, it saddens me deeply to have to be the one to inform you of his passing. He was a courageous, honest, and cheerful friend, well-liked by everyone in the society.

As a Professor at the University of Bordeaux, he worked as both a stomatologist and an oral surgeon. He also brilliantly presided over the Conseil National des Universités [National Council of Universities] in his later years. I think that many of our readers knew and appreciated him and his work. Even after his retirement, he kept very close ties with his friends in the society. He never missed the chance to meet us all at the SFCO conventions. Therefore, we all enjoyed having a drink with him on June 1,2018 , at the Paris convention, where despite having some health issues, he was still full of enthusiasm and ideas. We did not know that this would be the last time we saw him.

His successors at the Faculty of Dentistry of Bordeaux have already outlined his successful career in a tribute published in the previous issue of JOMOS, and now I would like to take the time to mention the type of man he was. I will always remember him as a great friend, who always worked to bring people together. I had the honor of chairing the Scientific Committee during his term as President of the SFCO. This allowed me to experience first-hand his talents and his extraordinary enthusiasm. It is difficult to fully describe his integrity and commitment to his work. During his presidency, the SFCO entered a new era of modernization. The fact that he was the first president who had been trained as an odontologist is certainly related to this.

I also had the great pleasure and honor to work with him at the Centre National des Concours d'Internat [National Center for Internships Competition]. Our Parisian meetings were a delight. Our subdivision (oral medicine and oral surgery) seemed to enjoy itself most of the time, rather than give the impression of working. Jacques often filled the time with entertaining and funny stories. He made us laugh at everything. All his jokes may not have been "politically
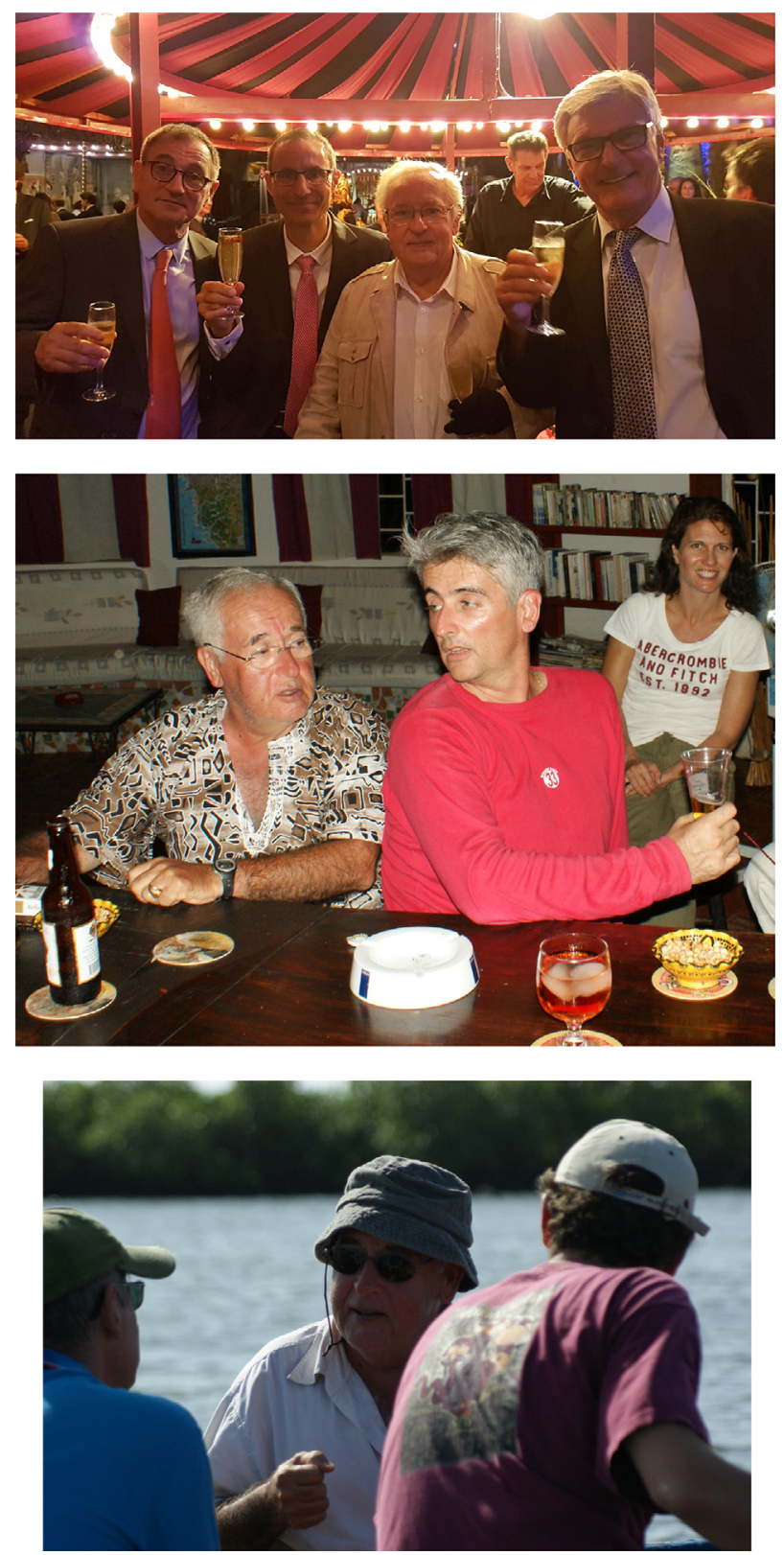
correct," but they were all hilarious and we loved listening to them, and miraculously, at the end of the day, when we returned our copy, it was clear that we had done more work than anyone else.

Jacques was a great traveler. He knew Vietnam, of course, for family reasons but had also visited every continent on his cruises. Africa! He told us of his trips with Concours Africain et Malgache pour l'Enseignement Supérieur (CAMES) [African and Malagasy Council for Higher Education]. I loved the story wherein at the end of the competition, he had to sleep in a prison cell, the only way to escape the violence that gripped the Ivory Coast. Also, I had the extraordinary opportunity to be part of a small group of friends he had got together during a conference in Dakar in 2009 in the Saloum Delta. We discovered a fabulous landscape, with thousands of birds flying overhead and the warmth of the locals whom we met as we fished in the river. Later, he also introduced us to sea fishing, but the only thing I caught was seasickness.
Not only did I discover the wonders of West Africa on this trip, but more importantly, I discovered the wonderful personality of Jacques, his generosity, and his good-humored nature.

As an insatiable traveler, Jacques, you had the luxury of passing away in Japan. As your wife, Roseline said, it was your last joke. The most extravagant perhaps, but the only one that does not make us laugh. You were a friend, a big brother, and a father figure for so many of us. Your smile and your mischievous nature will never cease to brighten our day. Because, beyond the friendships and relationships you've forged with us, beyond your incorruptible honesty, beyond the passing of time, you will always be a model for us to follow.

Jacques, we thank you.

Jacques-Henri Torres ${ }^{\star}$

University Hospital, 549 Avenue du Professeur JL Viala, 34295 Montpellier Cedex 5, France *Corresponding author: j-torres@chu-montpellier.fr 